\title{
Exacerbating Factors Induce Different Gene Expression Profiles in Peripheral Blood Mononuclear Cells from Asthmatics, Patients with Chronic Obstructive Pulmonary Disease and Healthy Subjects
}

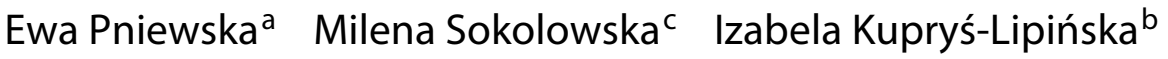 \\ Dorota Kacprzak $^{a}$ Piotr Kuna ${ }^{b}$ Rafal Pawliczak ${ }^{a}$ \\ ${ }^{a}$ Division of Allergology, Immunology and Dermatology, Department of Immunopathology, Faculty of Biomedical \\ Sciences and Postgraduate Training, and ${ }^{b}$ Department of Internal Diseases, Asthma and Allergy, Medical University \\ of Lodz, Lodz, Poland; ' Department of Critical Care Medicine, National Institutes of Health, Bethesda, Md., USA
}

\section{Key Words \\ Airway inflammation · Asthma $\cdot$ Chronic obstructive pulmonary disease - Exacerbating factors - House dust mites · Lipopolysaccharides - TaqMan low density array}

\begin{abstract}
Background: Despite several common phenotypic features, chronic obstructive pulmonary disease (COPD) and severe asthma differ with regard to their causative factors and pathophysiology. Both diseases may be exacerbated by environmental factors, however, the molecular profiles of disease episodes have not been comprehensively studied. We identified differences in gene and protein expression profiles expressed by peripheral blood mononuclear cells (PBMC) of COPD patients, patients with atopic asthma and healthy subjects when challenged with exacerbating factors in vitro: lipopolysaccharide (LPS), house dust mite (HDM) and cat allergen. Methods: PBMC isolated from patients with severe atopic asthma and COPD, as well as healthy subjects were stimulated with rDer $p 1$ DG, rFel d 1 DG and LPS. The changes in the expression of 47 genes belonging to five groups (phospholipase $A_{2}$, eicosanoids, transcription factors, cytokines and airway remodeling) were studied using
\end{abstract}

TaqMan low density array cards. Immunoblotting was used to study relative protein expression. Results: rDer $\mathrm{p} 1$ significantly up-regulated the expression of PLA2G4A, PLA2G6, PLA2G15, CYSLTR1, LB4R2, PTGS1, PTGS2, FOXP1, GATA3, HDAC2, IREB2, PPARG, STAT4, TSLP and CHI3L1 genes in asthmatics in comparison to healthy subjects. LPS induced significant expression of $A N X A 1$ and $L T A 4 H$ in asthmatics when compared to COPD patients and healthy subjects. SOX6, STAT4 and ILIRL1 were induced in COPD after LPS stimulation. Analysis of protein expression revealed a pattern similar to mRNA expression. Conclusions: LPS-induced exacerbation of asthma and COPD is characterized by differential expression of selected genes in PBMC. HDM allergen changed the expression profile of inflammatory genes between patients with asthma of atopic origin and healthy controls.

ㄷ) 2015 S. Karger AG, Basel

\section{Introduction}

Both asthma and chronic obstructive pulmonary disease (COPD) are airway diseases with a number of common phenotypic features, such as chronic airway inflammation and impaired airflow. However, important differ-

\section{KARGER}

E-Mail karger@karger.com

www.karger.com/iaa
(C) 2015 S. Karger AG, Basel

$1018-2438 / 15 / 1654-0229 \$ 39.50 / 0$
Correspondence to: Dr. Rafal Pawliczak

Department of Immunopathology, Medical University of Lodz

7/9 Zeligowskiego, Building 2, Room 122

PL-90-752 Lodz (Poland)

E-Mail rafal.pawliczak@ csk.umed.lodz.pl 
ences exist between asthma and COPD pathogenesis. In total, $70 \%$ of asthma cases have an atopic origin, whereas COPD is usually associated with cigarette smoking and exposure to noxious agents. In addition, the distribution of causative agents in the respiratory tract influence disease localization: while asthma affects the large and small airways, COPD impairs the function of small airways [1]. Furthermore, while asthma starts early in life, COPD is usually diagnosed in patients older than 45 years. Mast cells, Th CD4+ cells and eosinophils play a pivotal role in asthma, and neutrophils, Th CD8+ and macrophages characterize COPD inflammation. Despite these differences, acute exacerbation presents in both diseases and sometimes requires hospitalization. However, it is not clear whether exacerbating factors initiate the same cascade of signaling pathways in both diseases.

Causative factors, either allergens or viral/bacterial infections, are known to lead to inflammation enhancement. Airway inflammation is characterized by the presence of many inflammatory mediators, among which lipid derivatives have been described in detail. Leukotrienes and prostaglandins are responsible for airway muscle contraction, wheezing and mucus secretion. Their production is initiated by the release of arachidonic acid through the action of phospholipase $A_{2}$. Our previous studies have shown that cytosolic phospholipase $\mathrm{A}_{2}$ is involved in the pathogenesis of asthma [2,3]. Moreover, the involvement of different phospholipases in asthma and COPD pathogenesis has been stated recently [4]. The cells that are recruited in large number to the airways as well as those in the peripheral blood start to produce cytokines in response to trigger factors [5-10]. Activation of transcription factors, such as SOX6, FOXP1, GATA3, HDAC2, STAT4, IREB2 and PPARG, influence the course of inflammation. Through binding to the CtBP2 co-repressor and HDAC1-histone deacetylase, SOX6 is able to induce transrepression. Moreover, it might block canonical Wnt signaling in $\mathrm{T}$ cells $[11,12]$ and facilitates cardiac and skeletal muscle differentiation [13]. Bhattacharya et al. [14] demonstrated that SOX6 expression 7in peripheral blood mononuclear cells (PBMC) of COPD patients positively correlated with lung function. FOXP1 is a transcription factor involved in lung development, cell proliferation and differentiation, as well as signal transduction $[15,16]$. It regulates monocyte differentiation and macrophage function [17] and through interaction with $\mathrm{HDAC}_{2}$, it can influence IL-6 expression [18]. GATA3 is a transcription factor involved in T-cell development and promotes the secretion of IL-4, IL-5 and IL-13. Genomewide association studies identified an association be- tween IRBE2, one of the genes located in chromosome region 15q25.1, and COPD as well as airway obstruction [19].

Persistent airway inflammation finally results in airway remodeling and lack of airway elasticity. Metalloproteinases and chitinases participate in this process $[20,21]$. Matrix metalloproteinase (MMP)-9 has been shown to increase during COPD exacerbation, and its level has been correlated with neutrophil and lymphocyte counts in sputum [22]. The CHI3L1 gene encodes YKL-40, a chitinase-like protein also known as human cartilage glycoprotein-39. Although chitinase-like proteins differ from chitinases in so far that the former binds to chitin but does not hydrolyze it, while the latter possesses catalytic properties, both enzymes are able to modulate immune responses. YKL-40 acts as a soluble mediator of cell proliferation and migration $[23,24]$. Its level correlates with asthma severity and airway remodeling measured as the thickness of the subepithelial basement membrane [25]. Moreover, polymorphisms in $\mathrm{CHI} 3 \mathrm{~L} 1$ are associated with the risk of atopy $[26,27]$. However, comprehensive data elucidating the molecular changes induced by exacerbating factors in both COPD and asthma more clearly are still lacking.

The present study uses PBMC as an experimental model for two reasons. Changes in PBMC are easily observable, and they can be easily employed for possible diagnostic approaches. The presence of systemic inflammation in chronic diseases also influences the function of PBMC: T lymphocytes have been reported to have impaired function in COPD, and the monocytes of COPD patients produce more MMP-9 and IL-6, and show NF- $\kappa B$ activation [28]. The existence of systemic inflammation in COPD is associated with the presence of systemic COPD comorbidities, including chronic heart failure, diabetes and arteriosclerosis [29]. Systemic inflammation in asthma is less prominent, but increased levels of peripheral eosinophils has been found to correlate with disease severity and lung function [30]. Patients with allergic rhinitis and asthma have a higher percentage of Th17 lymphocytes than healthy controls, and exposure to allergen further increases their number $[31,32]$. In addition, total leukocyte counts and blood markers such as C-reactive protein are elevated in asthmatics [33]. Most blood monocytes of asthmatics are known to be CD14+/CD16+ and show features of tissue macrophages, such as enhanced release of superoxide anions, and glucocorticoids may influence the numbers of CD14++/CD16+ and CD14+/CD16+ monocytes in asthma patients $[34,35]$. Monocytes and CD4+ T cells 
from patients with allergic rhinitis express a number of phenotypic alternations [36].

The aim of the present study was to determine how $\mathrm{PBMC}$ of asthmatics and COPD patients respond to key exacerbating factors: allergen in asthma and LPS in asthma and COPD.

\section{Materials and Methods}

\section{Reagents}

LoTox ${ }^{\mathrm{TM}}$ deglycosylated recombinant Dermatophagoides pteronyssinus allergen 1 (rDer p 1 DG) and LoTox deglycosylated recombinant Felis domesticus allergen 1 (rFel d 1 DG) were purchased from Indoor Biotechnologies (Cardiff, UK). LPS from Escherichia coli serotype R515 was obtained from Enzo Life Sciences (New York, N.Y., USA). TaqMan low density array (TLDA) cards and a high-capacity cDNA kit were ordered from Life Technologies (Carlsbad, Calif., USA). Histopaque 1077, RPMI 1640, FBS, penicillin, streptomycin, RIPA buffer and protease inhibitor cocktail were purchased from Sigma-Aldrich (St. Louis, Mo., USA). Polymyxin B and BCIP/NBT alkaline phosphatase substrate were purchased from Merck Millipore (Darmstadt, Germany). The RNeasy cell mini kit with QIAshredder and DNAse set were purchased from Qiagen (Hilden, Germany). The BCA protein assay kit was ordered from Pierce Thermo Scientific (Rockford, Ill., USA). The following antibodies were used: annexin- 1 and $\beta$-actin from Cell Signaling (Danvers, Mass., USA); iPLA ${ }_{2}, \mathrm{LTA}_{4} \mathrm{H}$ and COX-2 from Cayman Chemical (Ann Arbor, Mich., USA); $\mathrm{HDAC}_{2}$ and PPAR- $\gamma$ from Santa Cruz Biotechnology (Dallas, Tex., USA), and PLA 2 XV and YKL-40 from Abcam (Cambridge, Mass., USA).

\section{Patients}

Patients with severe asthma of atopic origin or COPD, as well as healthy volunteers, were enrolled in the study. The project was approved by the local bioethical committee and informed consent was obtained from all the subjects. The subjects were recruited from the Department of Internal Diseases, Asthma and Allergy of the Medical University of Lodz. Asthma had to be diagnosed at least 6 months prior to the study and meet the criteria of the Global Initiative for Asthma [37]. The severity of the disease was assessed according to the American Thoracic Society Workshop on Refractory Asthma 2000 report [38]. COPD patients were enrolled in the study if they met the following criteria: (a) presence of clinical symptoms of chronic airway inflammation confirmed by persistent cough with sputum production lasting more than 3 months/ year during the last 2 years, (b) $\mathrm{FEV}_{1}<80 \%$ and $\mathrm{FEV}_{1} / \mathrm{FVC}$ ratio $<70 \%$, (c) a negative bronchodilator test, and (d) lack of other dysfunctions in the respiratory tract. Nonatopic subjects with a negative family history of allergy and asthma were included as healthy controls.

Patients were asked to abstain from antihistamine drugs, oral glucocorticoids or leukotriene receptor antagonists for $24 \mathrm{~h}$, and glucocorticoid inhalation or long-acting $\beta$-agonist use $12 \mathrm{~h}$ before blood was drawn.

Detailed characteristics of the patients and controls are shown in table 1.

Gene Expression in PBMC from

Asthmatics and COPD Patients
Table 1. Parameters and characteristics of severe asthmatics, COPD patients and controls

\begin{tabular}{llll}
\hline Parameter & Asthmatics & COPD & $\begin{array}{l}\text { Healthy } \\
\text { controls }\end{array}$ \\
\hline $\mathrm{n} \quad$ Males/females & $11 / 9$ & 6 & 7 \\
Race & Caucasian & Caucasian & Caucasian \\
Age, years & 48 & 63 & 41 \\
$\quad$ Range & $36-69$ & $53-71$ & $29-56$ \\
FEV & 75.9 & 47.8 & N/A \\
$\quad$ Range & $55-94$ & $41-55$ & - \\
FEV $/$ FVC & 68.7 & 50.8 & N/A \\
$\quad$ Range & $56.8-86.1$ & $40.1-58.6$ & - \\
PEF, liters & 5.8 & 3.85 & N/A \\
$\quad$ Range & $3.3-9.3$ & $2.7-6.5$ & - \\
Allergic to HDM & 10 & 0 & 0 \\
Allergic to cat dander & 8 & 0 & 0 \\
Current/nonsmokers & $0 / 0$ & $1 / 5$ & $0 / 0$ \\
\hline
\end{tabular}

Data are presented as means and ranges. $\mathrm{PEF}=$ Peak expiratory flow.

\section{Methods}

PBMC Isolation and Stimulation. PBMC were isolated by centrifugation on Histopaque 1077, a density gradient cell separation medium, according to the manufacturer's instructions. Cells were then cultured in RPMI 1640 with 10\% heat-inactivated FBS, $2 \mathrm{mM}$ L-glutamine and $10 \mathrm{ng} / \mathrm{ml}$ polymyxin $\mathrm{B}$ (allergens) or $100 \mathrm{U} / \mathrm{ml}$ penicillin and $100 \mu \mathrm{g} / \mathrm{ml}$ streptomycin. $2 \times 10^{6} / \mathrm{ml} \mathrm{PBMC}$ were stimulated in vitro with LoTox deglycosylated rDer $\mathrm{p} 1$ and LoTox deglycosylated rFel d 1 for 6 days or LPS from E. coli serotype R515 for $8 \mathrm{~h}$.

RNA Extraction and cDNA Synthesis. Total RNA was isolated from PBMC using the RNeasy cell mini kit with QIAshredder according to the manufacturer's instructions. RNA was DNase treated, purified, eluted in $30 \mu \mathrm{l}$ of RNase-free water and stored at $-80^{\circ} \mathrm{C}$ for further analysis. RNA was then reverse transcribed to cDNA using a high-capacity cDNA kit.

TLDA Cards. Each card of the low-density array contains eight separate loading ports that feed into 48 separate wells for a total of 384 wells per card. Each $2-\mu \mathrm{l}$ well contains a lyophilized TaqMan assay to enable a single gene to be detected. In this study, the TLDA card was configured into eight identical 48-gene sets (table 2). Each set of 48 genes also contains two reference genes: RNASEP1 and GAPDH. The coefficient of variation of $\mathrm{Cq}$ (quantification cycle) for the GAPDH reference gene between compared arrays was less than 5\%.

Real-Time PCR. $400 \mathrm{ng}$ of cDNA were used for each port of TLDA. The array was centrifuged twice for $1 \mathrm{~min}$ each at $306 \mathrm{~g}$ to distribute the samples from the loading port into each well. The card was then sealed and quantitative PCR (qPCR) was performed using an ABI Prism 7900HT sequence detection system (Applied Biosystems). RQ Manager 1.2.1 software was used to analyze raw qPCR data. The results were analyzed in comparison to the expression of the reference gene, using Livak's method, and presented as the relative expression of $\mathrm{mRNA}$ in the form of $\mathrm{RQ}=2^{-\Delta \Delta \mathrm{Cq}}$. The 
Table 2. Gene-specific results of allergen and LPS stimulation

\begin{tabular}{|c|c|}
\hline $\begin{array}{l}\text { Gene } \\
\text { symbol }\end{array}$ & Gene name \\
\hline \multicolumn{2}{|c|}{ Gene-specific results of $r$ Der $p 1$ stimulation } \\
\hline PLA2G4A & $\begin{array}{l}\text { phospholipase A2, group IVA (cytosolic, calcium } \\
\text { dependent) }\end{array}$ \\
\hline PLA2G6 & $\begin{array}{l}\text { phospholipase A2, group VI (cytosolic, calcium } \\
\text { independent) }\end{array}$ \\
\hline PLA2G15 & phospholipase A2, group XV \\
\hline PTGS1 & $\begin{array}{l}\text { prostaglandin-endoperoxide synthase } 1 \\
\text { (prostaglandin } \mathrm{G} / \mathrm{H} \text { synthase and cyclooxygenase) }\end{array}$ \\
\hline PTGS2 & $\begin{array}{l}\text { prostaglandin-endoperoxide synthase } 2 \\
\text { (prostaglandin } \mathrm{G} / \mathrm{H} \text { synthase and cyclooxygenase) }\end{array}$ \\
\hline CYSLTR1 & cysteinyl leukotriene receptor 1 \\
\hline$L T B 4 R$ & leukotriene B4 receptor \\
\hline FOXP1 & forkheadbox P1 \\
\hline GATA3 & GATA binding protein 3 \\
\hline$H D A C 2$ & histone deacetylase 2 \\
\hline IREB2 & iron-responsive element binding protein 2 \\
\hline$P P A R G$ & peroxisome proliferator-activated receptor- $\gamma$ \\
\hline STAT4 & signal transducer and activator of transcription 4 \\
\hline TSLP & thymic stromal lymphopoietin \\
\hline CHI3L1 & chitinase 3-like 1 (cartilage glycoprotein-39) \\
\hline \multicolumn{2}{|c|}{ Gene-specific results of LPS stimulation } \\
\hline$A N X A 1$ & annexin A1 \\
\hline$L T A 4 H$ & leukotriene A4 hydrolase \\
\hline $\operatorname{IL1RL1}$ & interleukin 1 receptor-like 1 \\
\hline SOX6 & SRY (sex-determining region Y)-box 6 \\
\hline STAT4 & signal transducer and activator of transcription 4 \\
\hline
\end{tabular}

untreated sample was used as a calibrator. The $\log _{2}$ base transformation of the RQ value was used to show changes in gene expression (i.e. $\mathrm{RQ}=10 ; \log _{2} 10=3.332$ ).

Immunoblotting. Total protein from PBMC of patients with asthma and COPD and healthy controls was extracted in RIPA protein extraction buffer supplemented with protease inhibitor. Protein concentrations were determined by the BCA protein assay kit; $20 \mu \mathrm{g}$ of total protein were subjected to electrophoresis in $4-12 \%$ gels at $140 \mathrm{~V}$ and transferred to a nitrocellulose membrane using the eBlot Protein Transfer System. The membrane was blocked with 5\% nonfat milk in TBST for $1 \mathrm{~h}$ at room temperature. Then, membranes were incubated for $12 \mathrm{~h}$ at $4^{\circ} \mathrm{C}$ with the primary antibodies and subsequently for $1 \mathrm{~h}$ with secondary antibodies at room temperature. The band was developed using BCIP/NBT alkaline phosphatase substrate. Densitometric analysis of bands was performed with ImageJ 1.34s software (Wayne Rasband, National Institutes of Health, Bethesda, Md., USA) and the results are presented as fold change in optical density.

\section{Statistical Analyses}

Data were analyzed using Statistica software (v.10.0; StatSoft, Tulsa, Okla., USA). The distribution of the $\log _{2}$ data and the equality of variances were checked by Shapiro-Wilk and Levene's tests, respectively. Significant changes were determined by ANOVA with the Tukey post hoc test as multiple comparison procedure.
The same procedure was used for each comparison (severe asthma vs. healthy subjects and severe asthma vs. COPD vs. healthy subjects). Values of $\mathrm{p}<0.05$ were considered statistically significant.

\section{Results}

\section{Gene Expression}

D. pteronyssinus Allergen 1

Sensitivity to house dust mites (HDM) is a risk factor associated with the development of asthma [39]. Further exposure to allergen can cause symptom exacerbation, which increases patient suffering and requires additional medical expenditure. As the asthmatics who participated in our study were atopic to Der p 1, PBMC isolated from the blood of those patients were stimulated in vitro with rDer $\mathrm{p} 1$ allergen $(1 \mu \mathrm{g} / \mathrm{ml})$. qPCR was then used to study the expression of 47 genes involved in the pathophysiology of chronic airway inflammation.

Phospholipases $A_{2}$. The present study examined the expression of eight phospholipase $\mathrm{A}_{2}$, phospholipase $\mathrm{A}_{2}$ receptor $(P L A 2 R 1)$ and phospholipase $\mathrm{A}_{2}$ inhibitor ( $A N X A 1)$ genes. A 6-day stimulation with $r$ Der $\mathrm{p} 1$ caused significant up-regulation of $P L A_{2} G 4 A$ (asthmatics, A: $1.96 \pm 0.49$ vs. healthy controls, $\mathrm{H}: 0.27 \pm 0.36 ; \mathrm{p}=0.018)$, PLA2G15 (A: $1.65 \pm 0.41$ vs. H: $0.2 \pm 0.29 ; \mathrm{p}=0.02$ ) and PLA2G6 (A: $1.51 \pm 0.41$ vs. $\mathrm{H}: 0.32 \pm 0.21 ; \mathrm{p}=0.016)$ genes in asthmatics (fig. 1). Genes of low-molecular-weight secretory $\mathrm{PLA}_{2}$ (GIIA, $\mathrm{V}$ and $\mathrm{X}$ ) were hardly detectable in the participants. Expression of PAFAH1B and ANXA1 genes tended to be up-regulated in healthy controls in comparison to asthmatics, whereas a trend to increased PLA2G7 and PLA2R1 expression was observed in asthmatics.

Arachidonic Acid. Among the genes belonging to the eicosanoid pathway, four demonstrated significantly altered expression as a result of rDer $\mathrm{p} 1$ stimulation. Two genes of leukotriene receptors, CYSLTR1 (A: $1.28 \pm 0.32$ vs. $\mathrm{H}: 0.42 \pm 0.26 ; \mathrm{p}=0.005)$ and $\operatorname{LTB} 4 R 2(\mathrm{~A}: 1.03 \pm 0.31$ vs. $H: 0.14 \pm 0.27 ; \mathrm{p}=0.035)$, were up-regulated in both groups, but expression was higher in asthmatic patients. Also, expression of genes for COX-1 (PTGS1, A: $1.55 \pm$ 0.44 vs. $\mathrm{H}: 0.14 \pm 0.28 ; \mathrm{p}=0.04$ ) and COX-2 (PTGS2, A: $1.76 \pm 0.62$ vs. $\mathrm{H}:-0.05 \pm 0.48 ; \mathrm{p}=0.04)$ was increased in asthmatics (fig. 2).

Transcription Factors. A significant difference in the expression of six transcription factor genes was observed between asthmatics and controls (FOXP1, A: $1.29 \pm 0.41$ vs. $\mathrm{H}: 0.23 \pm 0.24, \mathrm{p}=0.02 ; G A T A 3, \mathrm{~A}: 1.24 \pm 0.41$ vs. $\mathrm{H}: 0.22 \pm 0.22, \mathrm{p}=0.04 ; H D A C 2, \mathrm{~A}: 1.74 \pm 0.38$ vs. H: $0.5 \pm$ 


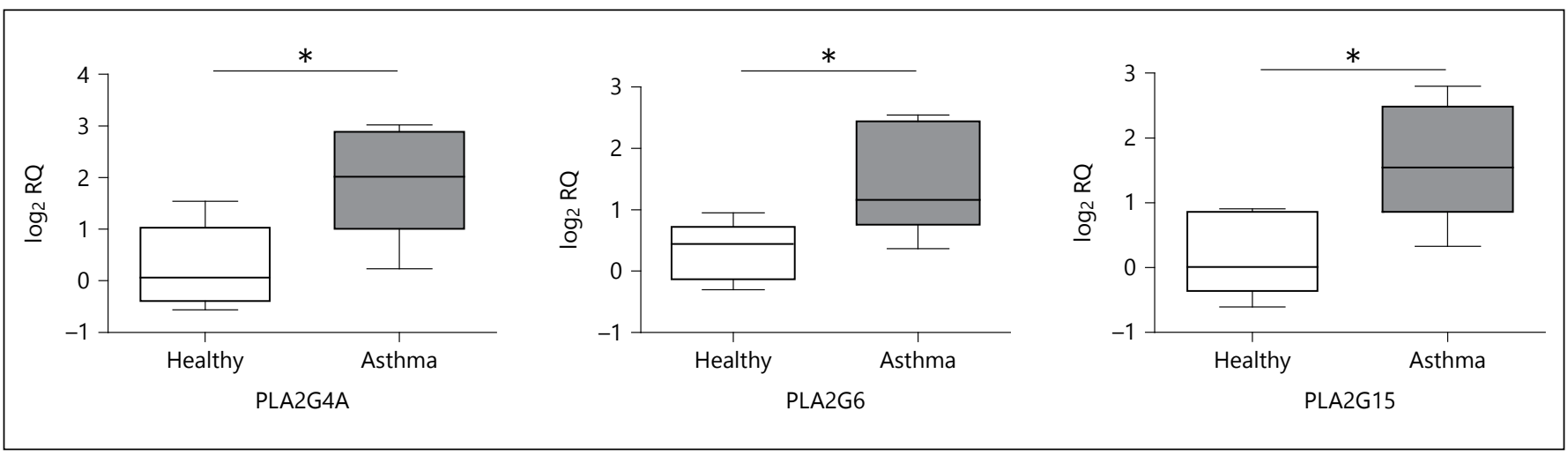

Fig. 1. Expression of phospholipase $A_{2}$ genes in PBMC of healthy controls $(n=5)$ and patients with severe asthma $(n=5)$ after stimulation with $\mathrm{rDer} p 1 \mathrm{DG}(1 \mu \mathrm{g} / \mathrm{ml})$. Means of $\log _{2} \mathrm{RQ} \pm \mathrm{SE}, * \mathrm{p}<0.05$.

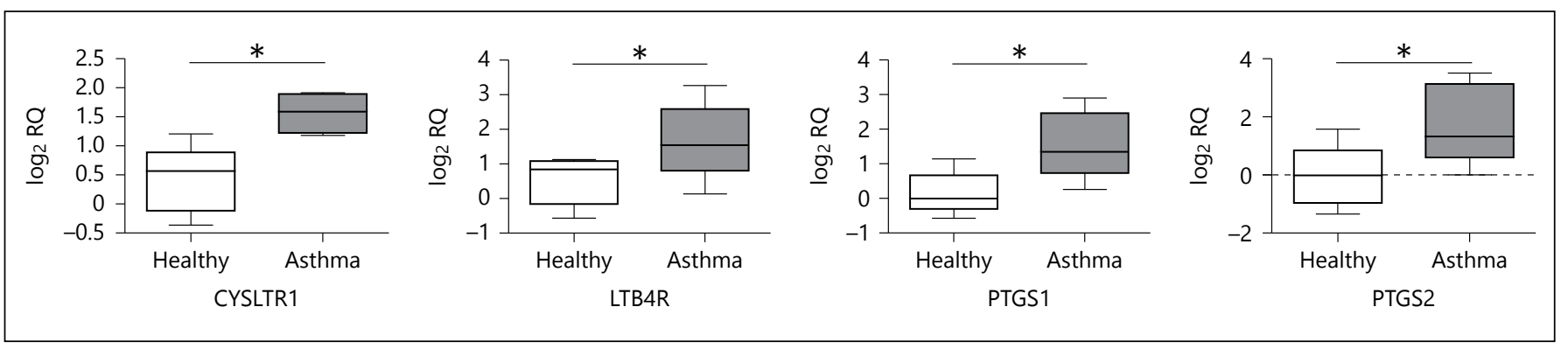

Fig. 2. Expression of eicosanoid pathway genes in PBMC of healthy controls $(n=5)$ and patients with severe asthma ( $n=5)$ after stimulation with rDer $\mathrm{p} 1 \mathrm{DG}(1 \mu \mathrm{g} / \mathrm{ml})$. Means of $\log _{2} \mathrm{RQ} \pm \mathrm{SE},{ }^{*} \mathrm{p}<0.05$.

$0.41, \mathrm{p}=0.04 ;$ IREB2, A: $1.3 \pm 0.36$ vs. H: $0.35 \pm 0.16, \mathrm{p}=$ 0.008 ; PPARG, A: $2.22 \pm 0.66$ vs. $\mathrm{H}: 0.43 \pm 0.26, \mathrm{p}=0.014$; STAT4, A: $1.18 \pm 0.41$ vs. H: $0.29 \pm 0.17, \mathrm{p}=0.04$; fig. 3 ). The $P P A R G$ gene was the highest expressed transcription factor gene in asthmatics.

Cytokines and Remodeling. PBMC of asthmatic patients showed increased expression of TSLP (A: $1.59 \pm$ 0.39 vs. $\mathrm{H}: 0.25 \pm 0.31 ; \mathrm{p}=0.02)$ and CHI3L1 (A: $2.29 \pm$ 0.73 vs. $\mathrm{H}: 0.39 \pm 0.27 ; \mathrm{p}=0.01)$ genes after stimulation with rDer p 1 (fig. 4). The IL33 gene was barely detected in both groups. All other cytokine genes show a tendency to a higher expression in asthmatics than controls.

\section{Lipopolysaccharides}

At least 50\% of COPD patients have bacteria in the lower airways during disease exacerbation, and, in most of them, the bacteria remain in the respiratory tract in the stable phase of COPD [40-42]. Bacteria may also worsen the course of asthma [43]. In the present study, PBMC from COPD patients, asthmatics and healthy subjects were stimulated with LPS $(100 \mathrm{ng} / \mathrm{ml})$ for $8 \mathrm{~h}$, and the differences in the expression of the studied genes were checked between groups.

Phospholipase $A_{2}$. PBMC stimulation with LPS resulted in significantly different expression of ANXA1 between asthmatics $(0.36 \pm 0.29)$, COPD patients $(-0.64 \pm$ $0.21)$ and controls $(-0.56 \pm 0.19 ; \mathrm{p}=0.04$; fig. 5$)$. Although not significant, the profiles of PLA2G15 and PLA2R1 expression were similar to that of ANXA1. A trend to increased expression of PLA2G4 and PLA2G7 was noted in all study groups. Genes for PLA2G2, PLA2G5 and $P L A 2 G 10$ were hardly detected. Only the PAFAH1B gene showed a tendency to be increased in healthy controls and COPD patients and down-regulated in asthmatics.

Arachidonic Acid. LTA4H was up-regulated in asthmatics $(0.5 \pm 0.38)$ and down-regulated in both COPD patients $(-0.87 \pm 0.27 ; \mathrm{p}=0.01)$ and healthy volunteers $(-0.74 \pm 0.25 ; \mathrm{p}=0.03$; fig. 6$)$. Of all the eicosanoid pathway genes, CYSLTR1, CYSLTR2 and LTB4R2 showed a trend to up-regulation in COPD and down-regulation in 


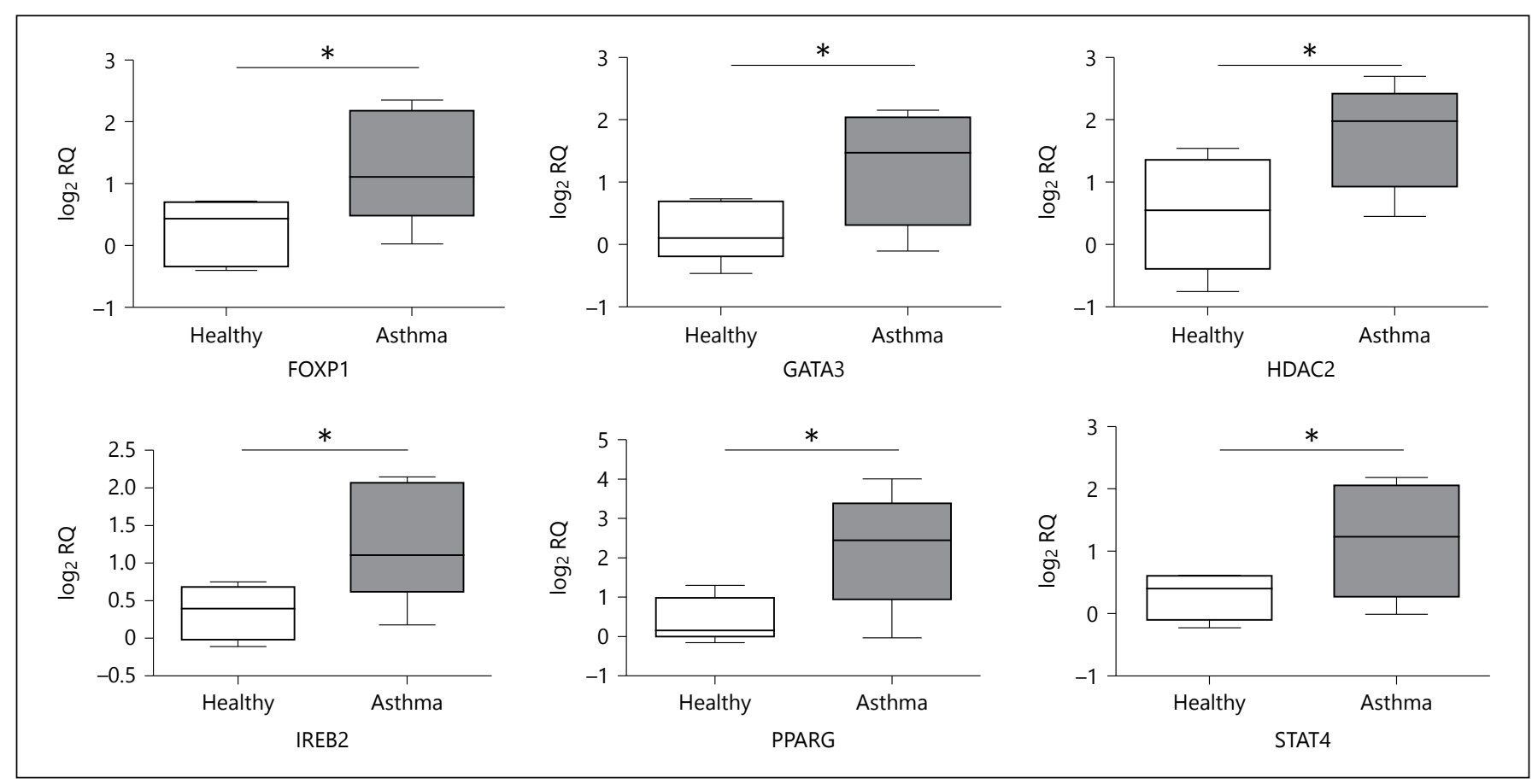

Fig. 3. Expression of transcription factor genes in PBMC of healthy controls $(n=5)$ and patients with severe asthma $(n=5)$ after stimulation with rDer $\mathrm{p} 1 \mathrm{DG}(1 \mu \mathrm{g} / \mathrm{ml})$. Means of $\log _{2} \mathrm{RQ} \pm \mathrm{SE}, * \mathrm{p}<0.05$.

Fig. 4. Expression of cytokine genes and genes related to airway remodeling in PBMC of healthy subjects $(n=5)$ and patients with severe asthma $(n=5)$ after stimulation with rDer p 1 DG $(1 \mu \mathrm{g} / \mathrm{ml})$. Means of $\log _{2} \mathrm{RQ} \pm \mathrm{SE}, * \mathrm{p}<0.05$.

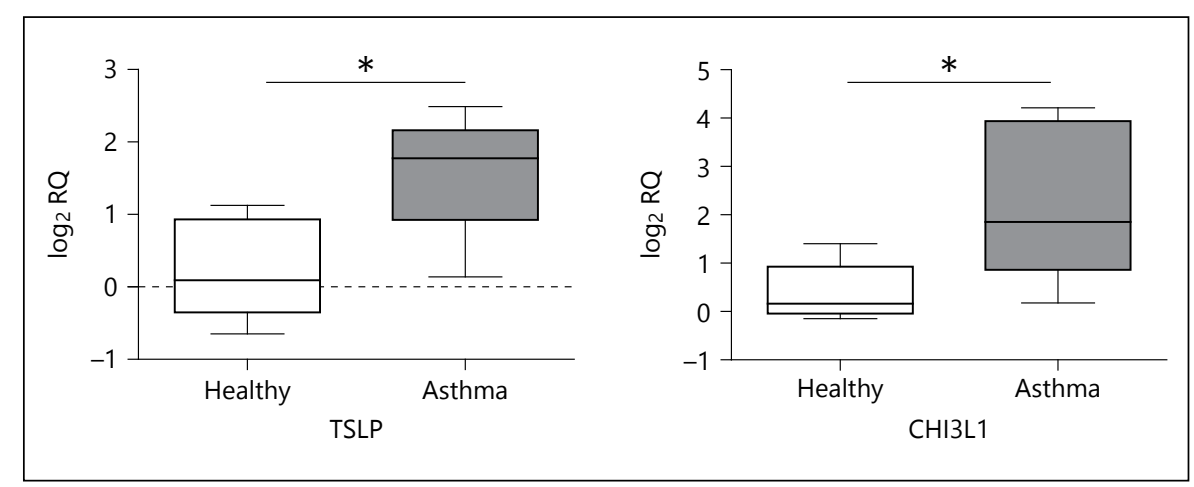

healthy controls and asthmatics. While not significant, PTGS2 and LTC4S genes exhibited a positive expression shift in all three groups, whereas PTGS1 expression was increased only in asthmatics. ALOX12 was found to have a tendency to be negatively regulated in asthmatics after LPS stimulation

Transcription Factors. LPS significantly changed the expression of SOX6 and STAT4 only in COPD patients (SOX6, $0.64 \pm 0.23$; STAT4, $0.77 \pm 0.35$ ) compared with the control group (SOX6, $-0.27 \pm 0.23, \mathrm{p}=0.008$; STAT4, $0.27 \pm 0.12, \mathrm{p}=0.04$; fig. 7). Although not significant, only $P P A R G$ gene expression was increased in asthmatics and down-regulated in COPD patients and healthy subjects.

Cytokines and Remodeling. After stimulation with LPS, PBMC from COPD patients $(1.47 \pm 0.37)$ displayed elevated expression of IL1RL1 in comparison to asthmatics $(0.72 \pm 0.3 ; \mathrm{p}=0.02)$ and healthy subjects $(0.95 \pm 0.22$; $\mathrm{p}=0.04$; fig. 8). The expression of all other cytokines showed a tendency to be increased after LPS treatment, with the highest RQ values being noticed for IL8 and $I L 1 B$. We did not observe significant changes in the expression of CHI3L1 and MMP9 in LPS-stimulated PBMC between asthmatics, COPD patients and healthy subjects. 


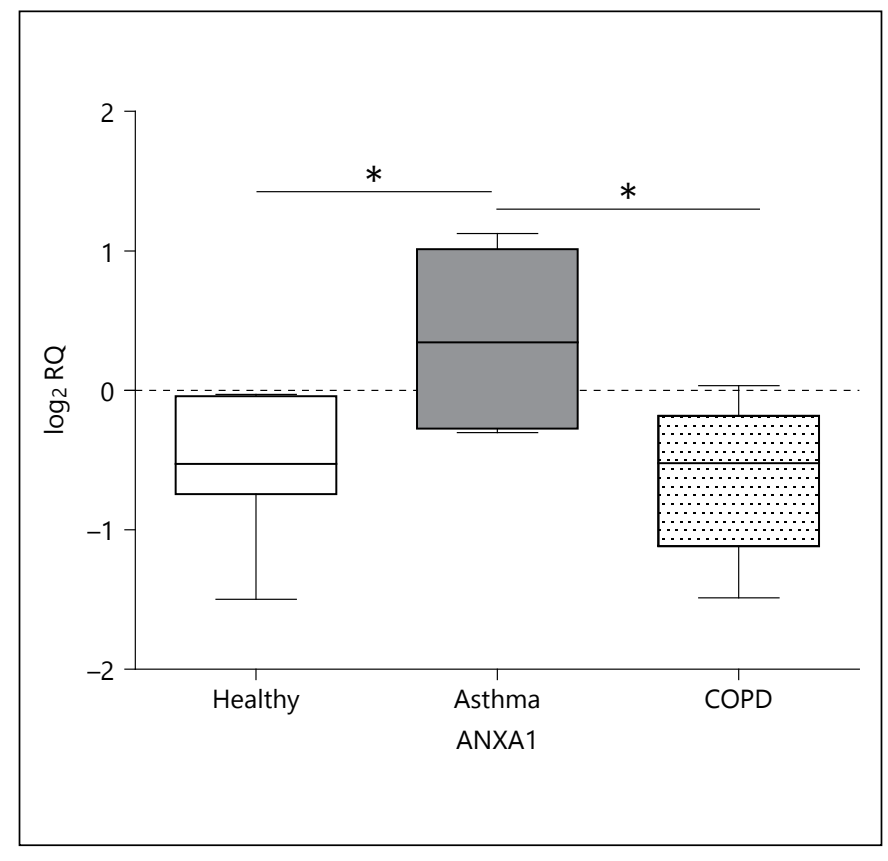

Fig. 5. Expression of the $A N X A 1$ gene in $\mathrm{PBMC}$ of healthy controls $(\mathrm{n}=7)$ and patients with severe asthma $(\mathrm{n}=5)$ and $\operatorname{COPD}(\mathrm{n}=6)$ after stimulation with LPS $(100 \mathrm{ng} / \mathrm{ml})$. Means of $\log _{2} \mathrm{RQ} \pm \mathrm{SE}$, $* \mathrm{p}<0.05$.

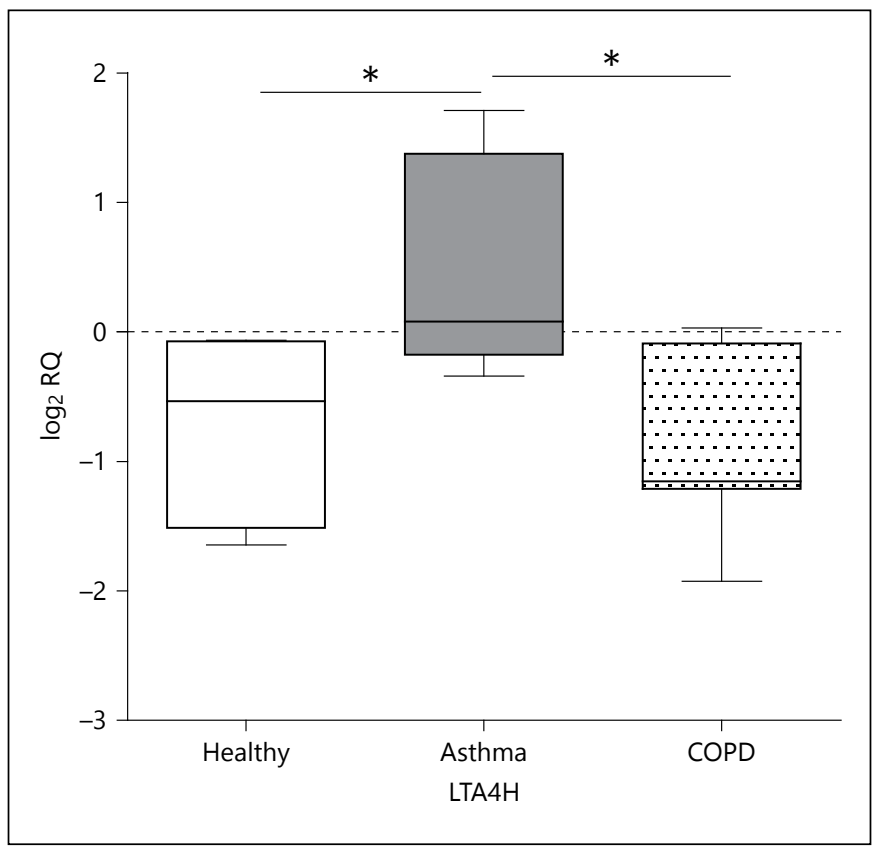

Fig. 6. Expression of the LTA4H gene in PBMC of healthy controls $(\mathrm{n}=7)$ and patients with severe asthma $(\mathrm{n}=5)$ and COPD $(\mathrm{n}=6)$ after stimulation with LPS $(100 \mathrm{ng} / \mathrm{ml})$. Means of $\log _{2} \mathrm{RQ} \pm \mathrm{SE}$, $* \mathrm{p}<0.05$.
Fig. 7. Expression of SOX6 and STAT4 genes in PBMC of healthy controls $(\mathrm{n}=7)$ and patients with severe asthma $(\mathrm{n}=5)$ and COPD $(n=6)$ after stimulation with LPS $(100 \mathrm{ng} / \mathrm{ml})$. Means of $\log _{2} \mathrm{RQ} \pm \mathrm{SE},{ }^{*} \mathrm{p}<$ 0.05 .

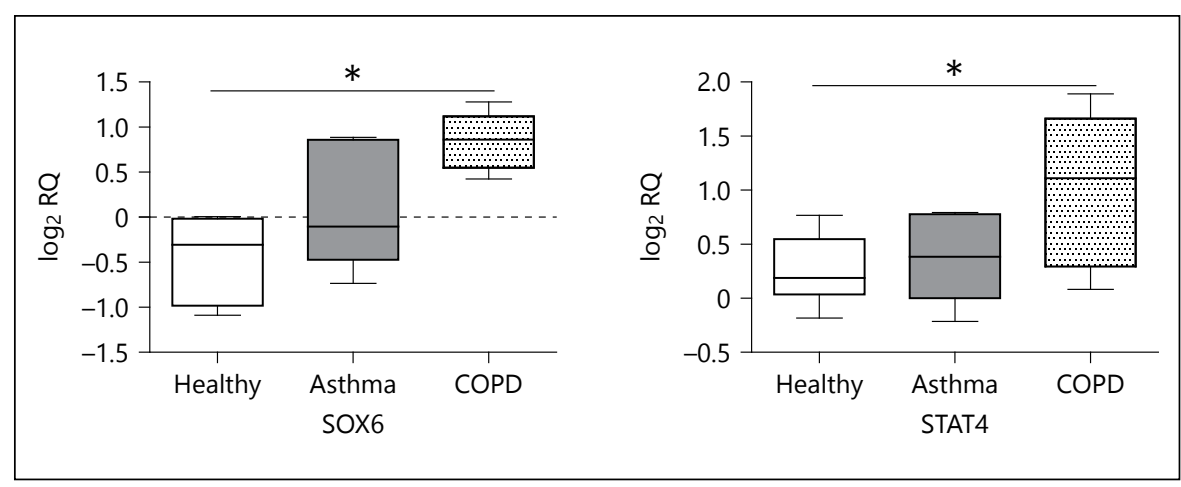

\section{Protein Expression}

Based on data from $\mathrm{qPCR}$, we assessed the relative protein expression of $\mathrm{CPLA}_{2} \alpha, \mathrm{iPLA}_{2}, \mathrm{PLA}_{2} \mathrm{XV}, \mathrm{COX}-2$, $\mathrm{HDAC}_{2}$, PPAR- $\gamma$, YKL-40 in PBMC of asthmatics and healthy subjects stimulated with rDer $\mathrm{p}$ 1. The relative expression of annexin 1 and $\mathrm{LTA}_{4} \mathrm{H}$ was measured in PBMC stimulated with LPS.

Phospholipases $A_{2}$. PBMC from asthmatics showed an increase in the relative protein expression of $\mathrm{PLA}_{2} \mathrm{XV}$ in comparison to healthy subjects (A: $0.14 \pm 0.06 ; \mathrm{H}$ : $-0.19 \pm 0.09)$. While not significant, the relative protein expression of $\mathrm{iPLA}_{2}$ and $\mathrm{CPLA}_{2} \alpha$ tended to be ele- vated in asthmatics (fig. 9). The relative protein expression of annexin-1 was increased in freshly isolated, untreated PBMC from COPD patients when compared with asthmatics and healthy subjects ( $\mathrm{H}: 0.26 \pm 0.01$ vs. A: $0.29 \pm 0.01$ vs. COPD: $0.44 \pm 0.8$ ). LPS caused a decrease in relative protein expression of annexin-1 in patients with $\mathrm{COPD}(\mathrm{H}: 0.13 \pm 0.16$ vs. COPD: $-0.3 \pm 0.22$; fig. 10)

Transcription Factors. The relative protein expression of $\mathrm{HDAC}_{2}$ and PPAR- $\gamma$ was assessed in PBMC stimulated with $\mathrm{rDer} \mathrm{p} 1$. Asthmatics showed decreased expression of $\mathrm{HDAC}_{2}$ (H: $0.11 \pm 0.05$ vs. A: $-0.29 \pm 0.16$; fig. 11). 
Fig. 8. Expression of the IL1RL1 gene in PBMC of healthy controls $(n=7)$ and patients with severe asthma $(\mathrm{n}=5)$ and COPD $(\mathrm{n}=6)$ after stimulation with LPS (100 ng/ $\mathrm{ml})$. Means of $\log _{2} \mathrm{RQ} \pm \mathrm{SE},{ }^{*} \mathrm{p}<0.05$.
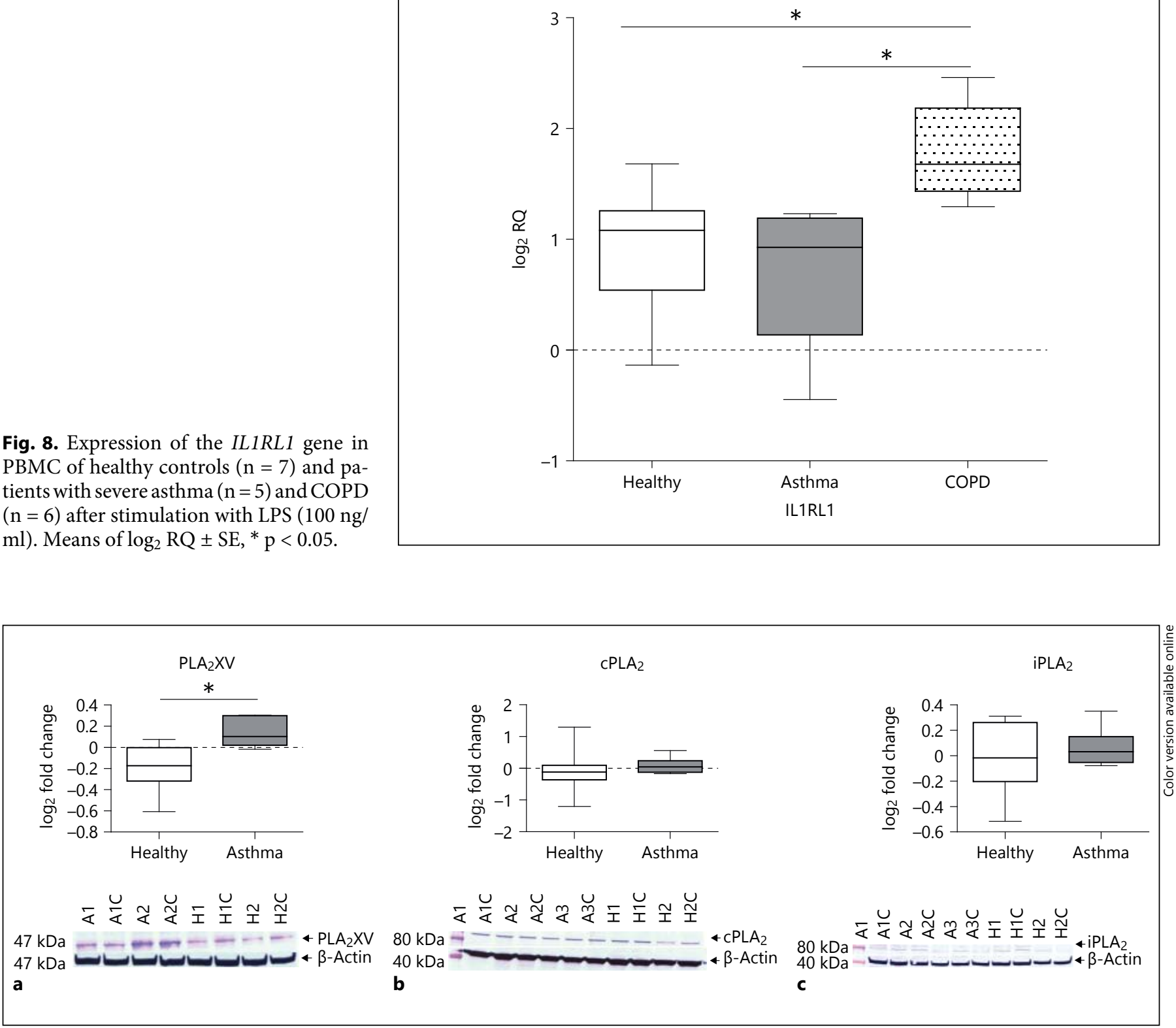

Fig. 9. Relative $\mathrm{PLA}_{2} \mathrm{XV}, \mathrm{cPLA}_{2} \alpha$ and $\mathrm{iPLA}_{2}$ protein expression in PBMC from healthy controls $(\mathrm{H})$ and asthmatic patients $(\mathrm{A})$ in vitro stimulated with rDer p 1 . PBMC $\left(2 \times 10^{6}\right)$ were stimulated with $1 \mu \mathrm{g} / \mathrm{ml} \mathrm{rDer} \mathrm{p} 1$ for 6 days. Immunoblots are representative of experiments in PBMC from 6 donors each showing similar re-

There were no differences in relative PPAR- $\gamma$ expression between the study groups.

Eicosanoid Pathway. The relative COX-2 expression was assessed in rDer $\mathrm{p}$ 1-stimulated PBMC from asthmatics and healthy controls as well as relative protein expression of $\mathrm{LTA}_{4} \mathrm{H}$ in LPS-stimulated PBMC from asthmatics, controls and COPD patients. Although not sults. The box plots show densitometric results. Data are presented as the fold change compared with the vehicle-treated cells (control) both normalized to $\beta$-actin. Means $\pm \mathrm{SE},{ }^{*} \mathrm{p}<0.05$. A1C, A2C, A3C, H1C, H2C = PBMC treated with medium only.

significant, both proteins had relative expression profiles similar to those introduced for mRNA expression (fig. 12).

Cytokines and Remodeling. Stimulation with $\mathrm{rDer} \mathrm{p} 1$ results in a significant difference in relative YKL-40 expression in PBMC between healthy controls $(-0.72 \pm$ $0.18)$ and asthmatics (0.12 \pm 0.07 ; fig. 13). 


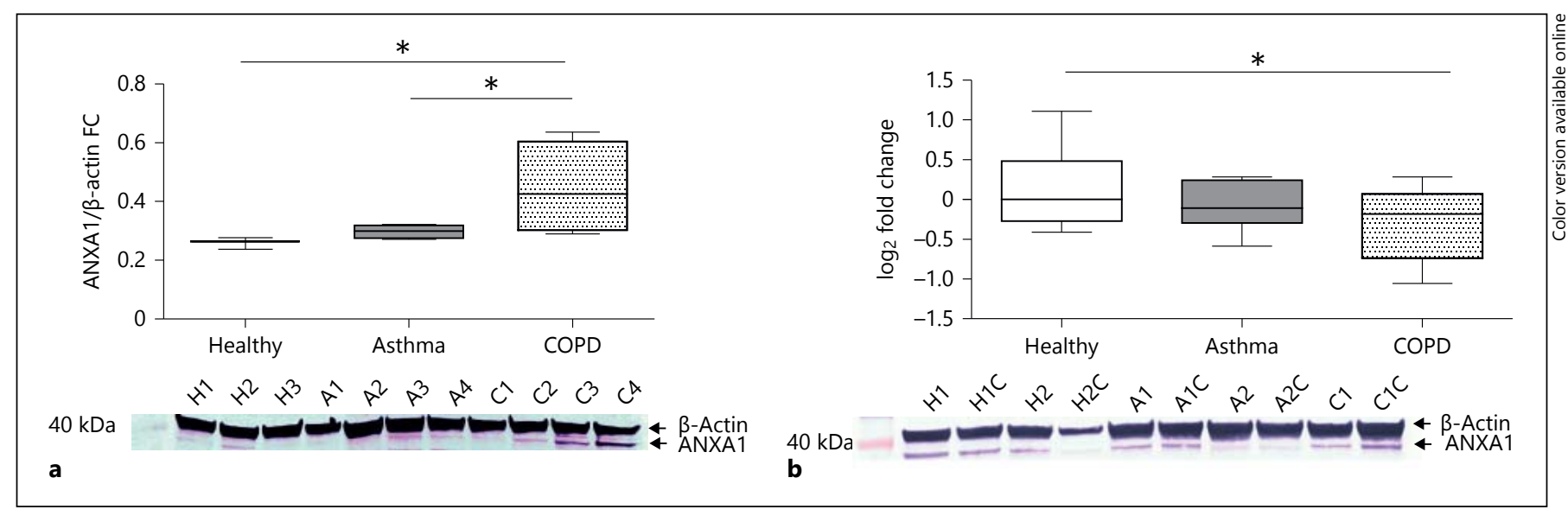

Fig. 10. Relative annexin-1 protein expression in PBMC from healthy controls $(\mathrm{H})$ and patients with asthma $(\mathrm{A})$ and COPD $(\mathrm{C})$ at baseline (a) and after in vitro stimulation with LPS (b). a Freshly isolated PBMC without culturing. b PBMC $\left(2 \times 10^{6}\right)$ stimulated with $100 \mathrm{ng} / \mathrm{ml}$ LPS for $8 \mathrm{~h}$. Immunoblots are representative of experiments in PBMC from 6 donors each showing similar results. The box plots show densitometry results. a Data normalized to $\beta$-actin. b Data compared with the vehicle-treated cells (control) both normalized to $\beta$-actin. Means $\pm \mathrm{SE},{ }^{*} \mathrm{p}<0.05$. A1C, A2C, $\mathrm{H} 1 \mathrm{C}, \mathrm{H} 2 \mathrm{C}, \mathrm{C} 1 \mathrm{C}=\mathrm{PBMC}$ treated with medium only.

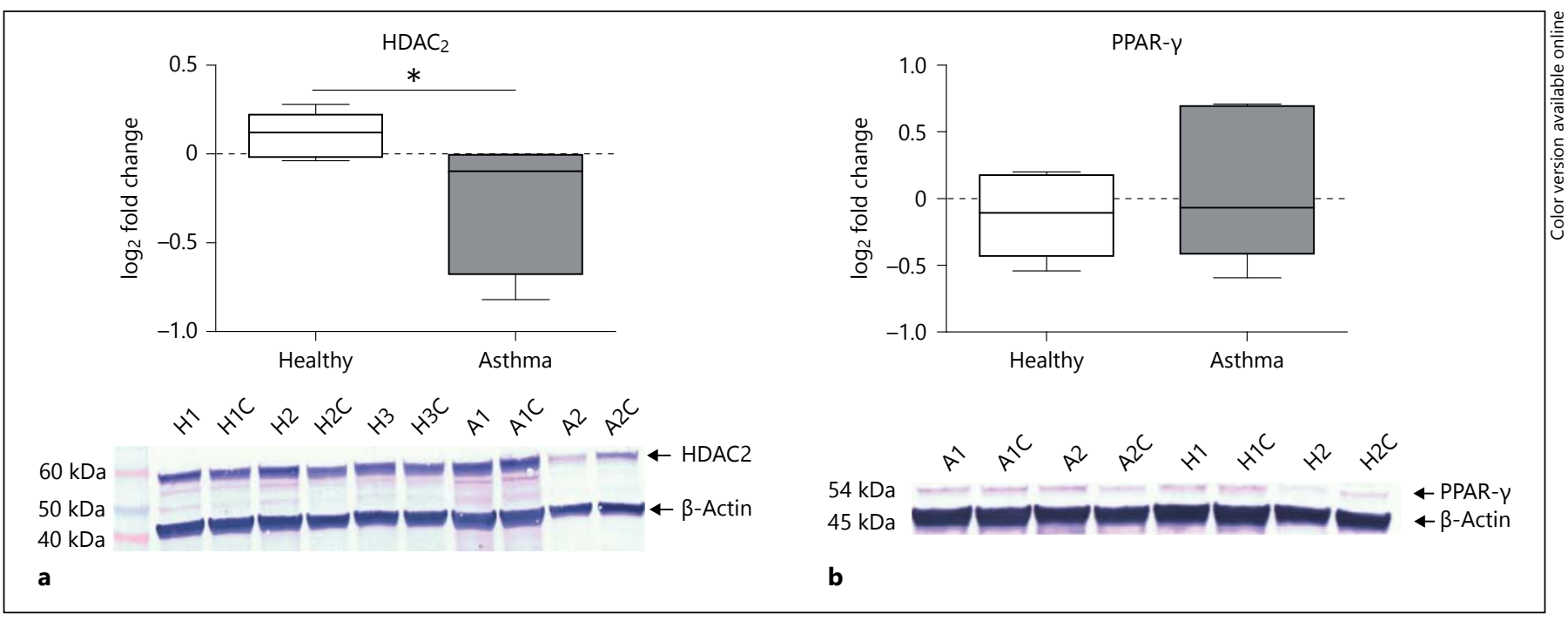

Fig. 11. Relative $\mathrm{HDAC}_{2}(\mathbf{a})$ and $\mathrm{PPAR}-\gamma(\mathbf{b})$ protein expression in PBMC from healthy controls $(\mathrm{H})$ and asthmatics $(\mathrm{A})$ stimulated in vitro with $\mathrm{rDer} \mathrm{p} 1$. PBMC $\left(2 \times 10^{6}\right)$ were stimulated with $1 \mu \mathrm{g} /$ $\mathrm{ml}$ rDer $\mathrm{p} 1$ for 6 days. Immunoblots are representative of experiments in PBMC from 6 donors each showing similar results. The

\section{Discussion}

Exacerbations in asthma and COPD are characterized by an enhanced inflammatory response, intensive recruitment of inflammatory cells and a higher concentration of inflammatory mediators. This explorative investigation assesses the response of PBMC isolated from atop- box plots show densitometry results. Data are presented as the fold change compared with the vehicle-treated cells (control) both normalized to $\beta$-actin. Means $\pm \mathrm{SE},{ }^{*} \mathrm{p}<0.05$. A1C, A2C, H1C, H2C = PBMC treated with medium only.

ic asthmatics, COPD patients and healthy subjects to three exacerbating factors: indoor HDM allergen (Der $\mathrm{p}$ 1), cat dander allergen (Fel d 1) and bacterial factor (LPS). As the COPD patients were not atopic and allergens are etiological factors of asthma, only PBMC of asthmatics were stimulated with allergens. However, as bacterial infection is known to worsen the course of both diseases, 


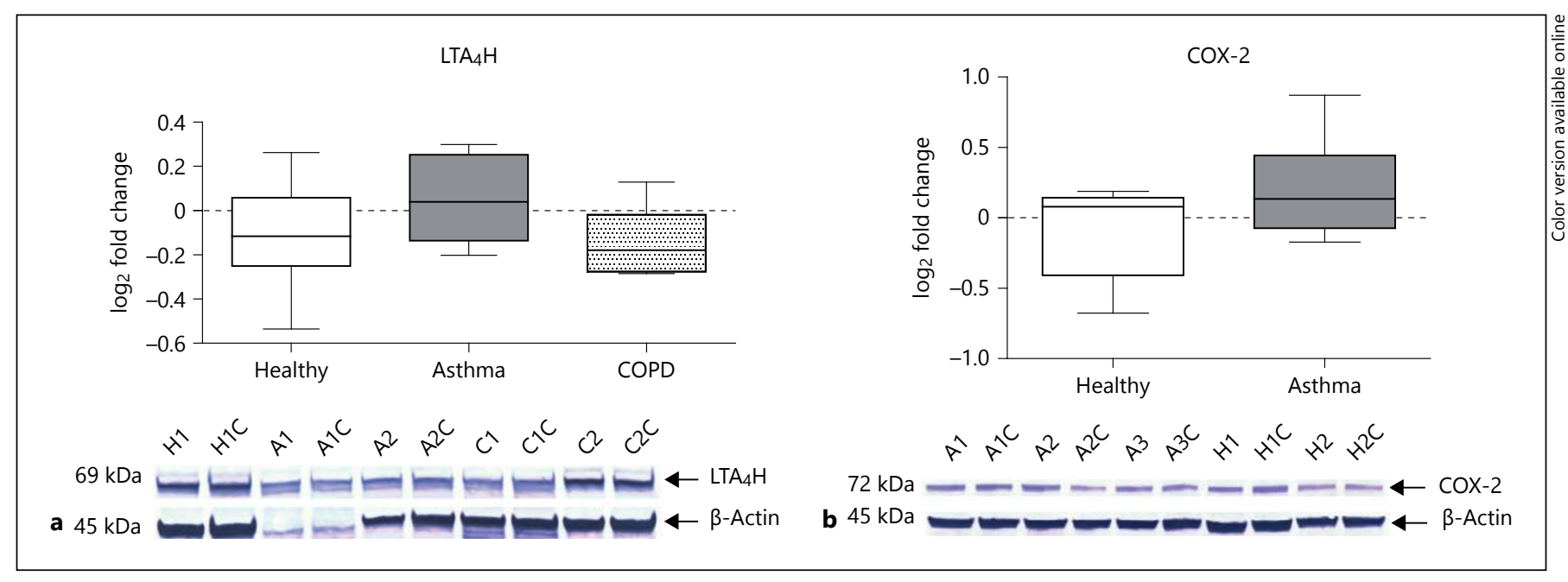

Fig. 12. Relative $\mathrm{LTA}_{4} \mathrm{H}$ expression in $\mathrm{PBMC}$ from healthy controls $(\mathrm{H})$ and patients with asthma (A) and COPD (C) stimulated with LPS (a) and relative COX-2 expression in PBMC stimulated in vitro with $\mathrm{rDer} \mathrm{p} 1(\mathbf{b})$. PBMC $\left(2 \times 10^{6}\right)$ were stimulated with $1 \mu \mathrm{g} / \mathrm{ml} \mathrm{rDer} \mathrm{p} 1$ for 6 days or $100 \mathrm{ng} / \mathrm{ml}$ LPS for $8 \mathrm{~h}$. Immunoblots are representative of experiments in PBMC from 6 donors each showing similar results. The box plots show densitometry results. a Data normalized to $\beta$-actin. b Data are presented as the fold change compared with the vehicle-treated cells (control) both normalized to $\beta$-actin. Means $\pm \mathrm{SE},{ }^{*} \mathrm{p}<0.05$. A1C, A2C, H1C, H2C, $\mathrm{C} 1 \mathrm{C}, \mathrm{C} 2 \mathrm{C}=\mathrm{PBMC}$ treated with medium only.

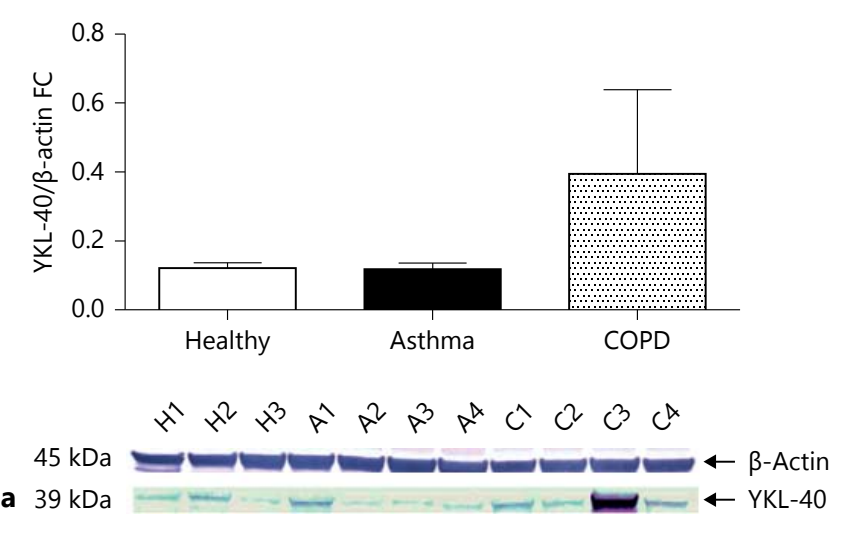

Fig. 13. Relative YKL- 40 protein expression in PBMC from healthy controls $(\mathrm{H})$ and patients with asthma $(\mathrm{A})$ and COPD $(\mathrm{C})$ at baseline (a) and after in vitro stimulation with rDer $\mathrm{p} 1$ (b). a Freshly isolated PBMC without culturing. b PBMC $\left(2 \times 10^{6}\right)$ stimulated with $1 \mu \mathrm{g} / \mathrm{ml} \mathrm{rDer} \mathrm{p} 1$ for 6 days. Immunoblots are representative

LPS was used to stimulate PBMC from both patient groups. We used recombinant allergens as the extracts may give false results [44]. The aim of the study was to determine, firstly, whether in vitro exposure to allergens differs between allergic asthmatics and healthy controls of experiments in PBMC from 6 donors each showing similar results. The box graph shows densitometry results. a Data normalized to $\beta$-actin. b Data presented as fold change compared with vehicletreated cells (control) both normalized to $\beta$-actin. Means $\pm \mathrm{SE},{ }^{*} \mathrm{p}<$ 0.05 . A1C, A2C, H1C, H2C = PBMC treated with medium only. 
tested agents has the greatest impact on the PBMC transcription profile in the groups studied.

The first group of genes analyzed comprised phospholipase $\mathrm{A}_{2}$ genes, $\mathrm{PLA}_{2}$ receptor and $\mathrm{PLA}_{2}$ inhibitor. rDer $\mathrm{p} 1$ was found to be the most potent inducer of their expression among the agents tested, and asthmatics were the group showing significant changes in their expression. The results from qPCR were used to study the relative protein expression of selected genes. The present study is the first to show that PLA2G15 can be regulated by Der $\mathrm{p} 1$ in the PBMC of asthmatics. PLA2G15, a relatively newly identified, $45-\mathrm{kDa}$ glycoprotein, was first discovered in 1996 [45] in canine MDCK cells and later in humans, but its biological function remains to be fully elucidated. It possesses $\mathrm{PLA}_{2}$ and PLA $\mathrm{P}_{1}$ activity insofar as it can hydrolyze the acyl chain at the sn- 1 and sn- 2 positions of phosphatidylcholine and phosphatidylethanolamine, and is localized in lysosomes. It is $\mathrm{Ca}^{2+}$ independent but shows increased activity in environments with low concentrations of $\mathrm{Ca}^{2+}$ or $\mathrm{Mg}^{2+}$. Currently, $\mathrm{PLA}_{2} \mathrm{G} 15$ is considered to be primarily an enzyme involved in lipid metabolism in alveolar macrophages and is believed to be associated with phospholipidosis. Further information related to the biological function of PLA2G15 has been obtained from recent studies on its role in iNKT cell-mediated CD1d recognition. The normal selection and maturation of iNKT cells requires complexes of CD1d with thymic lipids, whose generation is PLA2G15 dependent [46], which is particularly pertinent in this context, as iNKT cells can be activated by HDM extracts [47].

The data regarding transcriptional control of the PLA2G15 gene is limited. It has been established that retinoic acid stimulates PLA2G15 gene activation via an RXR-dependent pathway, but this effect was observed only in THP-1 cells, not in COS-7, MDCK or T293 cells [48]. The mechanism by which Der $\mathrm{p} 1$ exerts an impact on PLA2G15 expression remains to be established. Der $\mathrm{p}$ 1 can act by both the PAR- 2 receptor as well as in a PAR2 -independent manner by activation of NF-kB and ERK1/2 $[49,50]$. As the PLA2G15 gene has binding sites for NF-kB as well as for ATF-2, ELK-1, SP2-1 (Sabiosciences) and ERK1/2-regulated transcription factors, the involvement of the Der p 1-NF-kB pathway should be verified.

PBMC of asthmatics stimulated with rDer $\mathrm{p} 1$ showed increased expression of PLA2G4A in comparison to healthy controls. These results confirm those of a previous study where eosinophils isolated from asthmatics and challenged with Der $\mathrm{p} 1$ and Fel d 1 showed increased ac-

Gene Expression in PBMC from

Asthmatics and COPD Patients tivity and $\mathrm{CPLA}_{2}$ phosphorylation [51]. In addition, Whalen et al. [52] demonstrated that allergen-induced (Der $p$ 1 , Fel d 1 and ragweed) cytokine expression in PBMC is attenuated after inhibition of $\mathrm{CPLA}_{2} \alpha$. These observations suggest that allergens may influence the expression or activity of $\mathrm{CPLA}_{2} \alpha$. As cPLA ${ }_{2}$ and iPLA 2 (PLA2G6) also participate in leukocyte chemotaxis [53], increased expression of these proteins may also have an impact on further translocation of these cells. Although the differences in relative protein expression of $\mathrm{CPLA}_{2}$ and $\mathrm{iPLA}_{2}$ between asthmatics and controls were not significant, it was noticeable that the protein expression profile tended to be similar to the mRNA profile.

ANXA1, also known as lipocortin 1 , a PLA 2 inhibitor, was significantly changed in asthmatics after LPS stimulation. Inflammation is a self-resolving process and this can be achieved by activation of some anti-inflammatory genes such as ANXA-1. It has been demonstrated that a 6-hour stimulation with LPS results in increased ANXA expression in murine PBMC, which returns to the baseline value $24 \mathrm{~h}$ after stimulation [54]. This observed significant change can be a characteristic feature for the time point of stimulation chosen and not for long LPS action. Analysis of relative protein expression showed that COPD patients had significantly higher relative Anxa-1 expression than controls, however, LPS simulation resulted in decreased Anxa-1 concentrations. The regulation of gene expression includes many steps from mRNA synthesis to protein translation: processing of mRNA, transport of mRNA to the cytoplasm, translation and posttranslational modifications. All of these processes may be the potential cause of the observed differences between mRNA and protein expression.

The second group contained genes connected with the eicosanoid pathway. rDer $\mathrm{p} 1$ was found to significantly change the expression of PTGS1 and PTGS2 genes, and in this regard our results contradict those of Sánchez-Borges et al. [55] where HDM extract inhibited COX-1. The authors reported that this effect can be caused by COX1 -inhibitory substances in commercial mite allergenic extracts rather the allergen alone; the lack of any inhibitory effect observed in the present study can be explained by our use of the recombinant allergen (rDer p 1). On the other hand, Herrerias et al. [56] observed in a mouse model that HDM-induced airway hyperreactivity and inflammation were associated with increased COX2 mRNA production. In our experiments, Der $\mathrm{p} 1$ also induced the expression of LTB4R and CYSLTR1 genes. HDM allergens are able to stimulate the robust production of cysteinyl leukotriene from mouse bone marrow-derived dendritic cells [57] as well as to up-regulate the expression of 
CYSLTR1 on these cells [58]. These observations may suggest that eicosanoids are involved in the Der p 1-induced increase in inflammatory processes in asthma.

The third group consisted of cytokine genes. In our study, Der 1 significantly increased the expression of the TSLP gene. Thymic stromal lymphopoietin (TSLP) was reported to be produced by epithelial cells and keratinocytes, and known to influence the function of dendritic cells, which can further activate $\mathrm{T}$ cells. Only one study confirmed that human monocytes and monocyte-derived dendritic cells show TSLP gene expression, which can be also induced by LPS or zymosan [59]. Kashyap et al. [59] also noted that murine lung epithelial cells and dendritic cells produce TSLP in response to HDM extract. The ability of Der $p 1$ to induce TSLP secretion by BEAS$2 \mathrm{~B}$, a human bronchial epithelial cell line, was further confirmed by Al-Ghouleh et al. [60].

LPS was found to selectively and significantly up-regulate the expression of IL1RL1 (ST2) in COPD patients when compared with other groups. A recent study using a mouse model showed that the expression levels of IL-33 and ST2 were markedly enhanced in the lung tissue after inhalation of cigarette smoke [61]. This observation supports those presented by Hacker et al. [62], who reported increased serum levels of soluble ST-2 in COPD patients compared with healthy controls.

The fourth set comprised transcription factor genes, e.g. SOX6 and STAT4, which were significantly induced by LPS in COPD patients, and FOXP1, GATA3, HDAC2, STAT4, IREB2 and PPARG were up-regulated by $\mathrm{rDer} \mathrm{p}$ 1 allergen. In a mouse model, the STAT4 pathway was linked to allergen-induced chemokine production and airway hyperreactivity [63]. STAT4 is involved in IFN- $\beta$ induced MCP-1 mRNA expression in mast cells [64]. As both LPS and Der $\mathrm{p} 1$ were found to induce expression of the STAT4 gene, this pathway may be involved in LPSand allergen-induced airflow impairment during exacerbations. Macaubas et al. [65] reported that GATA3 expression is induced by HDM extract in the PBMC of atopic volunteers. As the authors suggested, monitoring of transcription factor expression can be used to control Th2 responses, and our study shows that this approach can also be used in patients with asthma of atopic origin. In the present study, IREB2 expression was elevated in $\mathrm{PBMC}$ of asthmatics after stimulation with rDer $\mathrm{p} 1$. It may be possible that these changes also occur after Der $p$ 1 -induced effects on the airways and hence may be involved in bronchial hyperreactivity.

rDer $\mathrm{p} 1$ was found to induce PPARG and HDAC2 expression in asthmatics when compared with changes in- duced in healthy controls. Both genes are known to be involved in the process of attenuating inflammation rather than its promotion. Generally, HDAC2 expression is thought to be decreased in asthmatics. We observed this trend in $\mathrm{HDAC}_{2}$ protein analysis. The activation of the expression of both genes may be part of a protective mechanism which aims to balance the inflammatory response which is also potentially dangerous to the cell.

The fifth group of genes related to airway remodeling analyzed consisted of ADAM-33, CHI3L1 and MMP9. All the tested agents influenced the expression of the CHI3L 1 gene, but a significantly higher level of mRNA was observed in asthmatics after Der p 1 stimulation in comparison to healthy controls. Also, relative protein expression was up-regulated. Our findings are in agreement with those of Kuepper et al. [66], who measured elevated YKL-40 concentrations in the serum and bronchoalveolar lavage fluid of asthmatics after segmental allergen challenge. Similarly, Lee et al. [67] observed elevated levels of YKL-40 after an allergen bronchial provocation test with Der $\mathrm{f} 1$ in induced sputum but not in the serum of asthmatic patients. Although the mechanism underlying the interaction between allergens and CHI 3 L1 remains unclear, one pathway may involve AP-1 and NF- $\kappa \mathrm{B}$ transcription factors, as it has been established that Der $\mathrm{p} 1$ acts by AP- 1 and NF- $\kappa B[50,68]$, and YKL-40 expression is $\mathrm{AP}-1$ and NF- $\kappa \mathrm{B}$ dependent $[69,70]$.

The results of the present study indicate that $r$ Der $p 1$ is a more potent inducer of gene expression than rFel d 1 . After stimulation with $\mathrm{rFel} d \mathrm{~d}$, no significant differences in expression were observed between asthmatics and healthy controls (additional data are presented as online suppl. materials, www.karger.com/doi/10.1159/000370067). However, two factors could exert an influence on these findings: the low number of study participants and the reduced ability of $\mathrm{rFel} \mathrm{d} 1$ to change the expression of the studied genes in PBMC.

Our study has some limitations. We employed PBMC to study allergen-/LPS-specific responses. They are easily accessible and widely used in in vitro studies, which is in contrast to airway tissue or lavage samples [71]. However, it has been noted that technical aspects of blood sampling, isolation of PBMC, RNA isolation techniques and time to analysis and temperature during blood processing may affect gene expression patterns [72, 73]. The PBMC population is heterogeneous. It includes lymphocytes, $\mathrm{T}$ and B cells (70-90\%), NK cells, monocytes (10-30\%) and dendritic cells (1-2\%). In humans, the frequencies of these populations vary across individuals. It seems rationale to assess the composition of the studied cell samples before 
experiments. Lineage-specific markers for T (CD3), B (CD19, CD20) and NK cells (CD56) and monocytes (CD14) may be used [72]. Because multiple markers can be used to identify these compartments, frequencies may vary according to the different markers used.

\section{Conclusions}

The study shows that the expression of five genes (ANXA1, LTA4H, IL1RL1, STAT4 and SOX6) in the PBMC of asthmatics, COPD patients and healthy subjects are differentially regulated by a bacterial factor responsible for the exacerbation of both diseases. rDer $p 1$ was the most potent inducer of the studied genes. Relative protein expression confirmed the observed differences at mRNA level. The present data may provide a basis for more sophisticated studies addressing differences in the course and exacerbation of asthma and COPD.

\section{Acknowledgments}

Support for this paper was obtained from a science budget for years 2010-2013 as research project (N N402 516939) and a Medical University of Lodz grant (503/0-149-03/503-01).

\section{Disclosure Statement}

The authors declare that they have no conflicts of interests.

\section{References}

1 Barnes PJ: Mechanisms in COPD: differences from asthma. Chest 2000;117:10S-14S.

-2 Sokolowska M, Stefanska J, Wodz-Naskiewicz K, Cieslak M, Pawliczak R: Cytosolic phospholipase A2 group IVA is overexpressed in patients with persistent asthma and regulated by the promoter microsatellites. J Allergy Clin Immunol 2010;125:1393-1395.

3 Sokolowska M, Borowiec M, Ptasinska A, Cieslak M, Shelhamer JH, Kowalski ML, et al: $85-\mathrm{kDa}$ cytosolic phospholipase A2 group IValpha gene promoter polymorphisms in patients with severe asthma: a gene expression and case-control study. Clin Exp Immunol 2007;150:124-131.

-4 Pniewska E, Pawliczak R: The involvement of phospholipases A2 in asthma and chronic obstructive pulmonary disease. Mediators Inflamm 2013;2013:793505.

5 Abbal C, Persi L, Bousquet J, Yssel H, Pène J: Effect of bronchial allergen challenge on in vitro cytokine release by peripheral blood mononuclear cells of atopic patients. Allergy 1998;53:945-950.

6 Aldonyte R, Jansson L, Piitulainen E, Janciauskiene S: Circulating monocytes from healthy individuals and COPD patients. Respir Res 2003;4:11.

-7 Fahy O, Hammad H, Sénéchal S, Pestel J, Tonnel AB, Wallaert B, et al: Synergistic effect of diesel organic extracts and allergen Der $\mathrm{p} 1$ on the release of chemokines by peripheral blood mononuclear cells from allergic subjects: involvement of the map kinase pathway. Am J Respir Cell Mol Biol 2000;23: 247-254.

-8 Fukuda T, Mochida S, Fukushima Y, Makino S: Detection of allergen-induced genes in peripheral blood mononuclear cells of patients with allergic asthma using subtractive hybridization. J Allergy Clin Immunol 1995;96:1076-1082. $\checkmark 9$ Haselden BM, Syrigou E, Jones M, Huston D, Ichikawa K, Chapman MD, et al: Proliferation and release of IL-5 and IFN-gamma by peripheral blood mononuclear cells from catallergic asthmatics and rhinitics, non-cat-allergic asthmatics, and normal controls to peptides derived from Fel d 1 chain 1. J Allergy Clin Immunol 2001;108:349-356.

10 Nocker RE, Schoonbrood DF, van de Graaf EA, Hack CE, Lutter R, Jansen HM, et al: Interleukin-8 in airway inflammation in patients with asthma and chronic obstructive pulmonary disease. Int Arch Allergy Immunol 1996;109:183-191.

11 Murakami A, Ishida S, Thurlow J, Revest JM, Dickson C: SOX6 binds CtBP2 to repress transcription from the Fgf-3 promoter. Nucleic Acids Res 2001;29:3347-3355.

12 Iguchi $\mathrm{H}$, Urashima Y, Inagaki Y, Ikeda Y, Okamura M, Tanaka T, et al: SOX6 suppresses cyclin D1 promoter activity by interacting with beta-catenin and histone deacetylase 1 , and its down-regulation induces pancreatic beta-cell proliferation. J Biol Chem 2007;282: 19052-19061.

13 Hagiwara N, Ma B, Ly A: Slow and fast fiber isoform gene expression is systematically altered in skeletal muscle of the Sox6 mutant, p100H. Dev Dyn 2005;234:301-311.

14 Bhattacharya S, Tyagi S, Srisuma S, Demeo DL, Shapiro SD, Bueno R, et al: Peripheral blood gene expression profiles in COPD subjects. J Clin Bioinforma 2011;1:12.

15 Lai E, Clark KL, Burley SK, Darnell JE: Hepatocyte nuclear factor $3 /$ fork head or 'winged helix' proteins: a family of transcription factors of diverse biologic function. Proc Natl Acad Sci U S A 1993;90:10421-10423.

16 Giannattasio G, Lai Y, Granata F, Mounier $\mathrm{CM}$, Nallan L, Oslund R, et al: Expression of phospholipases A2 in primary human lung macrophages: role of cytosolic phospholipase A2-alpha in arachidonic acid release and platelet activating factor synthesis. Biochim Biophys Acta 2009;1791:92-102.

-17 Shi C, Sakuma M, Mooroka T, Liscoe A, Gao $\mathrm{H}$, Croce KJ, et al: Down-regulation of the forkhead transcription factor Foxp1 is required for monocyte differentiation and macrophage function. Blood 2008;112:4699-4711.

18 Chokas AL, Trivedi CM, Lu MM, Tucker PW Li S, Epstein JA, et al: Foxp1/2/4-NuRD interactions regulate gene expression and epithelial injury response in the lung via regulation of interleukin-6. J Biol Chem 2010;285:1330413313.

19 Wilk JB, Shrine NR, Loehr LR, Zhao JH, Manichaikul A, Lopez LM, et al: Genome-wide association studies identify CHRNA5/3 and HTR4 in the development of airflow obstruction. Am J Respir Crit Care Med 2012;186: 622-632.

20 Gueders MM, Foidart JM, Noel A, Cataldo DD: Matrix metalloproteinases (MMPs) and tissue inhibitors of MMPs in the respiratory tract: potential implications in asthma and other lung diseases. Eur J Pharmacol 2006; 533:133-144

21 Bara I, Ozier A, Girodet PO, Carvalho G, Cattiaux J, Begueret H, et al: Role of YKL-40 in bronchial smooth muscle remodeling in asthma. Am J Respir Crit Care Med 2012;185: 715-722.

-22 Mercer PF, Shute JK, Bhowmik A, Donaldson GC, Wedzicha JA, Warner JA: MMP-9, TIMP-1 and inflammatory cells in sputum from COPD patients during exacerbation. Respir Res 2005;6:151.

23 Kzhyshkowska J, Gratchev A, Goerdt S: Human chitinases and chitinase-like proteins as indicators for inflammation and cancer. Biomark Insights 2007;2:128-146.
Gene Expression in PBMC from

Asthmatics and COPD Patients
Int Arch Allergy Immunol 2014;165:229-243 DOI: 10.1159/000370067 
24 Shuhui L, Mok YK, Wong WS: Role of mammalian chitinases in asthma. Int Arch Allergy Immunol 2009;149:369-377.

25 Chupp GL, Lee CG, Jarjour N, Shim YM, Holm CT, He S, et al: A chitinase-like protein in the lung and circulation of patients with severe asthma. N Engl J Med 2007;357:20162027.

-26 Sohn MH, Lee JH, Kim KW, Kim SW, Lee SH, Kim KE, et al: Genetic variation in the promoter region of chitinase 3-like 1 is associated with atopy. Am J Respir Crit Care Med 2009; 179:449-456.

27 Rathcke CN, Holmkvist J, Husmoen LL, Hansen T, Pedersen O, Vestergaard $\mathrm{H}$, et al: Association of polymorphisms of the CHI3L1 gene with asthma and atopy: a populationsbased study of 6514 Danish adults. PLoS One 2009;4:e6106.

28 Aldonyte R, Jansson L, Piitulainen E, Janciauskiene S: Circulating monocytes from healthy individuals and COPD patients. Respir Res 2003;4:11.

29 Magnussen H, Watz H: Systemic inflammation in chronic obstructive pulmonary disease and asthma: relation with comorbidities. Proc Am Thorac Soc 2009;6:648-651.

-30 Bousquet J, Chanez P, Lacoste JY, Barnéon G, Ghavanian N, Enander I, et al: Eosinophilic inflammation in asthma. N Engl J Med 1990; 323:1033-1039.

-31 Bajoriuniene I, Malakauskas K, Lavinskiene S, Jeroch J, Sakalauskas R: Th17 response to Dermatophagoides pteronyssinus is related to late-phase airway and systemic inflammation in allergic asthma. Int Immunopharmacol 2013;17:1020-1027.

- 32 Ciprandi G, Castellazzi AM, Fenoglio D, Battaglia F, Marseglia G: Peripheral TH-17 cells in children with allergic rhinitis: preliminary report. Int J Immunopathol Pharmacol 2010;23:379-382.

33 Girdhar A, Kumar V, Singh A, Menon B, Vijayan VK: Systemic inflammation and its response to treatment in patients with asthma. Respir Care 2011;56:800-805.

-34 Rivier A, Pène J, Rabesandratana H, Chanez P, Bousquet J, Campbell AM: Blood monocytes of untreated asthmatics exhibit some features of tissue macrophages. Clin Exp Immunol 1995;100:314-318.

-35 Moniuszko M, Bodzenta-Lukaszyk A, Kowal K, Lenczewska D, Dabrowska M: Enhanced frequencies of $\mathrm{CD} 14++\mathrm{CD} 16+$, but not CD14+CD16+, peripheral blood monocytes in severe asthmatic patients. Clin Immunol 2009; 130:338-346.

-36 Moniuszko M, Kowal K, Jeznach M, Rusak M, Dabrowska M, Bodzenta-Lukaszyk A: Phenotypic correlations between monocytes and CD4+ T cells in allergic patients. Int Arch Allergy Immunol 2013;161:131-141.

37 Global Initiative for Asthma: Global Strategy for Asthma Management and Prevention: Updated 2011. www.ginasthma.org.

-38 Proceedings of the ATS Workshop on Refractory Asthma: current understanding, recom- mendations, and unanswered questions. American Thoracic Society. Am J Respir Crit Care Med 2000;162:2341-2351.

39 Sears MR, Herbison GP, Holdaway MD, Hewitt CJ, Flannery EM, Silva PA: The relative risks of sensitivity to grass pollen, house dust mite and cat dander in the development of childhood asthma. Clin Exp Allergy 1989; 19:419-424

40 Sethi S, Murphy TF: Infection in the pathogenesis and course of chronic obstructive pulmonary disease. N Engl J Med 2008;359: 2355-2365.

41 Monsó E, Rosell A, Bonet G, Manterola J, Cardona PJ, Ruiz J, et al: Risk factors for lower airway bacterial colonization in chronic bronchitis. Eur Respir J 1999;13:338-342.

42 Pela R, Marchesani F, Agostinelli C, Staccioli D, Cecarini L, Bassotti C, et al: Airways microbial flora in COPD patients in stable clinical conditions and during exacerbations: a bronchoscopic investigation. Monaldi Arch Chest Dis 1998;53:262-267.

43 Kraft M: The role of bacterial infections in asthma. Clin Chest Med 2000;21:301-313.

44 Casset A, Mari A, Purohit A, Resch Y, Weghofer M, Ferrara R, et al: Varying allergen composition and content affects the in vivo allergenic activity of commercial Dermatophagoides pteronyssinus extracts. Int Arch Allergy Immunol 2012;159:253-262.

45 Abe A, Shayman JA, Radin NS: A novel enzyme that catalyzes the esterification of $\mathrm{N}$-acetylsphingosine. Metabolism of C2ceramides. J Biol Chem 1996;271:1438314389.

-46 Paduraru C, Bezbradica JS, Kunte A, Kelly R, Shayman JA, Veerapen N, et al: Role for lysosomal phospholipase A2 in iNKT cell-mediated CD1d recognition. Proc Natl Acad Sci U S A 2013;110:5097-5102.

47 Wingender G, Rogers P, Batzer G, Lee MS, Bai $\mathrm{D}$, Pei B, et al: Invariant NKT cells are required for airway inflammation induced by environmental antigens. J Exp Med 2011;208: 1151-1162.

48 Abe A, Poucher HK, Hiraoka M, Shayman JA Induction of lysosomal phospholipase A2 through the retinoid $\mathrm{X}$ receptor in THP-1 cells. J Lipid Res 2004;45:667-673.

49 Kauffman HF, Tamm M, Timmerman JA, Borger P: House dust mite major allergens Der $\mathrm{p} 1$ and Der $\mathrm{p} 5$ activate human airwayderived epithelial cells by protease-dependent and protease-independent mechanisms. Clin Mol Allergy 2006;4:5.

50 Adam E, Hansen KK, Astudillo Fernandez O, Astudillo OF, Coulon L, Bex F, et al: The house dust mite allergen Der p 1, unlike Der p 3, stimulates the expression of interleukin-8 in human airway epithelial cells via a proteinase-activated receptor-2-independent mechanism. J Biol Chem 2006;281: 6910-6923.

-51 Seeds MC, Peachman KK, Bowton DL, Sivertson KL, Chilton FH: Regulation of arachidonate remodeling enzymes impacts eosinophil survival during allergic asthma. Am J Respir Cell Mol Biol 2009;41:358-366.

52 Whalen KA, Legault H, Hang C, Hill A, Kasaian $\mathrm{M}$, Donaldson $\mathrm{D}$, et al: In vitro allergen challenge of peripheral blood induces differential gene expression in mononuclear cells of asthmatic patients: inhibition of cytosolic phospholipase A2alpha overcomes the asthma-associated response. Clin Exp Allergy 2008;38:1590-1605.

53 Cathcart MK: Signal-activated phospholipase regulation of leukocyte chemotaxis. J Lipid Res 2009;50(suppl):S231-S236.

54 Damazo AS, Yona S, D’Acquisto F, Flower RJ, Oliani SM, Perretti M: Critical protective role for annexin 1 gene expression in the endotoxemic murine microcirculation. Am J Pathol 2005;166:1607-1617.

55 Sánchez-Borges M, Fernández-Caldas E, Capriles-Hulett A, Caballero-Fonseca F: Miteinduced inflammation: more than allergy. Allergy Rhinol (Providence) 2012;3:e25-e29.

56 Herrerias A, Torres R, Serra M, Marco A, Pujols L, Picado C, et al: Activity of the cyclooxygenase 2-prostaglandin-E prostanoid receptor pathway in mice exposed to house dust mite aeroallergens, and impact of exogenous prostaglandin E2. J Inflamm (Lond) 2009;6: 30.

57 Barrett NA, Maekawa A, Rahman OM, Austen KF, Kanaoka Y: Dectin-2 recognition of house dust mite triggers cysteinyl leukotriene generation by dendritic cells. J Immunol 2009;182:1119-1128.

-58 Barrett NA, Fernandez JM, Maekawa A, Xing W, Li L, Parsons MW, et al: Cysteinyl leukotriene 2 receptor on dendritic cells negatively regulates ligand-dependent allergic pulmonary inflammation. J Immunol 2012;189: 4556-4565.

59 Kashyap M, Rochman Y, Spolski R, Samsel L, Leonard WJ: Thymic stromal lymphopoietin is produced by dendritic cells. J Immunol 2011;187:1207-1211.

60 Al-Ghouleh A, Johal R, Sharquie IK, Emara M, Harrington H, Shakib F, et al: The glycosylation pattern of common allergens: the recognition and uptake of Der $\mathrm{p} 1$ by epithelial and dendritic cells is carbohydrate dependent. PLoS One 2012;7:e33929.

61 Qiu C, Li Y, Li M, Liu X, McSharry C, Xu D: Anti-interleukin-33 inhibits cigarette smokeinduced lung inflammation in mice. Immunology 2013;138:76-82.

62 Hacker S, Lambers C, Pollreisz A, Hoetzenecker $\mathrm{K}$, Lichtenauer $\mathrm{M}$, Mangold $\mathrm{A}$, et al: Increased soluble serum markers caspasecleaved cytokeratin-18, histones, and ST2 indicate apoptotic turnover and chronic immune response in COPD. J Clin Lab Anal 2009;23:372-379.

63 Raman K, Kaplan MH, Hogaboam CM, Berlin A, Lukacs NW: STAT4 signal pathways regulate inflammation and airway physiology changes in allergic airway inflammation locally via alteration of chemokines. J Immunol 2003;170:3859-3865. 
64 Iida K, Suzuki K, Yokota M, Nakagomi D, Wakashin $\mathrm{H}$, Iwata A, et al: STAT4 is required for IFN- $\beta$-induced MCP- 1 mRNA expression in murine mast cells. Int Arch Allergy Immunol 2011;155(suppl 1):71-76.

65 Macaubas C, Lee PT, Smallacombe TB, Holt BJ, Wee C, Sly PD, et al: Reciprocal patterns of allergen-induced GATA-3 expression in peripheral blood mononuclear cells from atopics vs. non-atopics. Clin Exp Allergy 2002;32:97-106.

-66 Kuepper M, Bratke K, Virchow JC: Chitinaselike protein and asthma. N Engl J Med 2008; 358:1073-1075; author reply 1075.

67 Lee JH, Park KH, Park JW, Hong CS: YKL-40 in induced sputum after allergen bronchial provocation in atopic asthma. J Investig $\mathrm{Al}$ lergol Clin Immunol 2012;22:501-507.
68 Wong CK, Li ML, Wang CB, Ip WK, Tian YP, Lam CW: House dust mite allergen Der $p 1$ elevates the release of inflammatory cytokines and expression of adhesion molecules in coculture of human eosinophils and bronchial epithelial cells. Int Immunol 2006;18:13271335.

69 Singh SK, Bhardwaj R, Wilczynska KM, Dumur CI, Kordula T: A complex of nuclear factor I-X3 and STAT3 regulates astrocyte and glioma migration through the secreted glycoprotein YKL-40. J Biol Chem 2011;286: 39893-39903.
70 Recklies AD, Ling H, White C, Bernier SM: Inflammatory cytokines induce production of CHI3L1 by articular chondrocytes. J Biol Chem 2005;280:41213-41221.

71 Bjornsdottir US, Holgate ST, Reddy PS, Hill AA, McKee CM, Csimma CI, et al: Pathways activated during human asthma exacerbation as revealed by gene expression patterns in blood. PLoS One 2011;6:e21902.

72 Debey S, Schoenbeck U, Hellmich M, Gathof BS, Pillai R, Zander T, et al: Comparison of different isolation techniques prior gene expression profiling of blood derived cells: impact on physiological responses, on overall expression and the role of different cell types. Pharmacogenomics J 2004;4:193-207.

73 Fan H, Hegde PS: The transcriptome in blood: challenges and solutions for robust expression profiling. Curr Mol Med 2005;5:3-10. 